\title{
CRIMINALISATION OF DAMAGE TO PROPERTY BY SOUTH AFRICAN COMMON-LAW CRIMES
}

\author{
Shannon Hoctor*
}

\section{ABSTRACT}

This contribution examines the common-law crimes of malicious injury to property and arson. The current definitions of the crimes are set out, before the historical development of each crime is critically evaluated. In the concluding part, the nature and structure of the crimes are explored in the context of the rationales underpinning the crimes. It is submitted that despite the expansion of the crime of arson through case law not being in accordance with the purpose of the crime, the current definition of this crime has been settled. It is, however, contended that the wider definition of malicious injury to property, flowing from certain cases and academic interpretation, is not similarly entrenched in South African law and that any similar extension to the ambit of this crime therefore should not form part of the current definition.

Keywords: malicious injury to property, arson, damage to property, case precedent

* Professor of Law, University of KwaZulu-Natal. I would like to express my gratitude to the anonymous reviewers of an earlier draft of this article for their perceptive and thoughtful comments. Whatever errors and infelicities remain are my own. 


\section{Introduction}

Damage to property has been subjected to criminal sanction in terms of two commonlaw crimes in South Africa: malicious injury to property and arson. ${ }^{1}$ It has been argued that since the elements of arson are all contained within the crime of malicious injury to property, there is no need for the crime of arson. ${ }^{2}$ It is, however, contended that the crimes are sufficiently distinguishable to merit the separate independent existence of arson. Both crimes are not merely defined in terms of punishing intentional and unlawful direct harm to the property of another, but also retain the possibility that criminal liability can extend to harm to the accused's own property, where that harm is accompanied by an intention to harm the proprietary interests of another. It was held in the recent authoritative judgement of the Supreme Court of Appeal in $S$ v Dalindyebo, ${ }^{3}$ that it is indeed appropriate for the intentional burning of the accused's own property to be regarded as arson where he foresees the possible risk of harm to others arising from his actions. In the light of this finding, the basis for the expansion of the crimes of malicious injury to property and arson into the context of selfinflicted damage, coupled with the intent to institute an associated insurance claim, which development has been subjected to criticism, ${ }^{4}$ is examined below.

Each of the crimes are defined in its current form, ${ }^{5}$ before proceeding to an evaluation of the historical development of each crime. In the final part of the contribution, the rationale for these crimes are further discussed, along with an evaluation of the validity of the extension of the ambit of these crimes.

\section{Defining malicious injury to property}

As indicated above, an issue of nomenclature needs to be resolved before this crime can be discussed, namely should the crime be described as "malicious injury to property" or as "malicious damage to property"? ${ }^{7}$ The former appellation is

1 As discussed below, some writers describe the first-mentioned crime as "malicious damage to property", and this alternative nomenclature has also been used in some cases. For the reasons that are explained here, this contribution will use the traditional terminology of "maliciousinjury to property". See part 2 infra.

2 Burchell 2016: 761 comments that "it is difficult logically to justify the existence of a crime separate from the crime of malicious injury to property (of which it is a species)".

$3 \quad$ S v Dalindyebo 2016 (1) SACR 329 (SCA).

4 This extension has been criticised by both De Wet 1985: 288-289, 294 and Snyman 2014: 540, 542 in respect of these crimes.

5 Since the focus of this contribution is on the basis of the extension of the ambit of the crimes, the elements of the crimes are necessarily dealt with briefly.

$6 \quad$ As do Snyman 2014: 539 and Milton 1996: 765.

7 The preferred choice of Burchell 2016: 757 and Kemp et al 2018: 455. 


\section{CRIMINALISATION OF DAMAGE TO PROPERTY}

incontestably more ancient. In the 1874 Cape case of $R v$ Reikert, ${ }^{8}$ the Attorney General argued that "indictments had been laid and convictions obtained in this Colony for the crime of malicious injury to property" since 1837 . Moreover, this term remains in frequent use to this day. ${ }^{9}$ The latter appellation is of much more recent vintage, ${ }^{10}$ although it has been used in some recent case law, ${ }^{11}$ and has been described by Burchell as "more accurate" and "favoured by the courts". ${ }^{12}$ With respect, neither of these justifications is entirely compelling. "Injury" and "damage" are synonyms, after all, ${ }^{13}$ and it is simply not true that the courts favour the term "malicious damage to property", as a brief overview of the case law reveals. ${ }^{14}$ The use of the term "malicious damage to property" may derive from the fact that it is a more direct translation from the Afrikaans term "saakbeskadiging", ${ }^{15}$ that it is one of the crimereporting categories used by the South African Police Service, ${ }^{16}$ that it is due to the inconsistencies of case reporting, ${ }^{17}$ or that it is due to legislative inconsistency. ${ }^{18}$

8 Queen v Reikert (1874) 4 Buch 142 at 143. For examples of early cases in other jurisdictions confirming the existence of the crime of malicious injury to property, see Queen v Johannes (1880-1881) 1 EDC 93; Queen v Charlie Shangaan (1883) 2 HCG 433; Stewart \& Willis v Rex 1903 TS 456; JJ Raw v Clerk of Peace, Pietermaritzburg County (1884) 5 NLR 292.

9 See, for example, Director of Public Prosecutions Transvaal $v$ Minister of Justice and Constitutional Development 2009 (2) SACR 130 (CC); S v Tonkin 2014 (1) SACR 583 (SCA); S $v$ Phetoe 2018 (1) SACR 593 (SCA).

10 First seen, it seems, in the reported case law in $R v$ Manuel 1959 (1) SA 677 (C).

11 See, for example, $S v$ Thebus 2003 (2) SACR 319 (CC); $S$ v Le Roux 2010 (2) SACR 11 (SCA); $S$ v Mlungwana 2019 (1) SACR 429 (CC).

12 Burchell 2016: 757. Kemp et al 2018: 455 does not indicate any reason for preferring this name for the crime.

13 In $S v$ Phetoe 2018 (1) SACR 593 (SCA), the terms "malicious damage to property" (par 1) and "malicious injury to property" (par 18) appear to be used interchangeably. Similarly, in $S v$ Kola 1966 (4) SA 322 (A) at 328B-C, the court (inaccurately) describes the conviction in $R v$ Mashanga 1924 AD 11 as "malicious damage to property" rather than as "malicious injury to property". Further, in the Concise Oxford Dictionary of Current English, "damage" is defined as "harm or injury" (my emphasis) and "injury" as "harm or damage" (my emphasis).

14 At its strongest, the most that can be said for Burchell's argument is that the courts employ both formulations. See, for example, the cases cited in nn 9-11 supra.

15 See Arnold v Terblanche 1961 (4) SA 229 (T) at 231C-F.

16 Social Justice Coalition v Minister of Police 2019 (4) SA 82 (WCC) par 44 n 32.

17 See, for example, $S v$ Fielies 2006 (1) SACR 302 (C), where the term "malicious damage to property" is employed in the headnote, despite the term "malicious injury to property" being used (par 11) of the judgement. Similarly, in S v Langa 2010 (2) SACR 289 (KZP), the term "malicious damage to property" is used in the headnote, despite the term "malicious injury to property" describing the count in question in the judgement (par 1).

18 Whereas the primary procedural statutes, namely the Criminal Procedure Act 51 of 1977 (at s 262 and Schedules 1 and 7) and the Child Justice Act 75 of 2008 (at Schedules 1 and 2), along with the Prevention of Organised Crime Act 121 of 1998 (at Schedule 1) and the Immigration Act 13 of 2002 (at Schedule 2) all refer to "malicious injury to property", the term "malicious damage to property" appears in other legislative instruments, such as the Game Theft Act 105 of 1991 (at s 7), the Firearms Control Act 60 of 2000 (at Schedule 2), the Private Security Industry Regulation Act 56 of 2001 (at the Schedule), and the Explosives Act 15 of 2003 (at Schedule 2). 
It is submitted that there is no need for the use of differing terms to describe the crime. Although the word "damage" is perhaps more likely to be used in current speech than "injury", this should not be determinative. While terms such as "burglary" and "blackmail" are frequently used in popular parlance and in the media to describe (respectively) the crimes of housebreaking with intent to commit a crime and extortion, there is no question of them replacing the nomenclature of the actual crimes. Moreover, even though "malicious damage to property" has crept into judicial and legislative usage, "malicious injury to property" was not only the original name for the crime, but has been used in all the leading judgements in which the law giving rise to the present crime has developed..$^{19}$ As indicated, it is still employed today in the most important procedural statutes and in numerous judgements, and thus is used for purposes of this contribution.

A final comment on nomenclature: if it is indeed the purpose of the courts or the legislature to adjust the description of the crime for the sake of clarity, as well as to accord with modern discourse, then the qualifier "malicious" ought to be dispensed with. In signifying that the crime can only be committed where the accused acts out of ill-will or some improper motive, it only serves as a possible source of confusion, ${ }^{20}$ and a violation of the principle of fair labelling, which requires that offences are so labelled so as to "ensure that the stigma (label) attaching to the accused by virtue of his conviction is a fair and accurate reflection of his guilt". ${ }^{21}$ The word "malicious" offers no guidance to the court, which simply assesses whether the conduct is intentional..$^{22}$

The crime of malicious injury to property may be defined as "unlawfully and intentionally damaging the property of another". ${ }^{23}$ Alternative definitions accommodate the extension of the crime by adding that the crime may also be committed by the unlawful and intentional damage of the accused's "own insured property, intending to claim the value of the property from the insurer", ${ }^{24}$ or of "property belonging to [the accused] in which [another person] has a substantial interest". ${ }^{25}$

There is unanimity among scholars as to the elements of the crime. ${ }^{26}$ These fall to be listed concisely. First, the conduct must be unlawful, in that it does not fall

19 See, for example, $R$ v Malamu Nkatlapaan 1918 TPD 424; $R$ v Mashanga 1924 AD 11; $R v$ Maruba 1942 OPD 51; and $S v$ Mtetwa 1963 (3) SA 445 (N).

20 Snyman 2014: 541; Milton 1996: 772-773.

21 Kemp et al 2018: 23.

$22 R v$ Mashanga 1924 AD 11 at 12; $R$ v Shelembe $1955(4) \mathrm{SA} 410(\mathrm{~N})$ at 411D; $S$ v Mnyandu 1973 (4) SA $603(\mathrm{~N})$ at $605 \mathrm{H}$.

23 Milton 1996: 765; Burchell 2016: 757; De Wet 1985: 288; $R$ v Mashanga 1924 AD 11 at 12.

24 Snyman 2014: 539.

25 Kemp et al 2018: 456, following S v Mnyandu 1973 (4) SA 603 (N) at 606A.

26 Milton 1996: 765ff; Burchell 2016: 757ff; De Wet 1985: 288-290; Snyman 2014: 539-541; Kemp et al 2018: 456-457; Hoctor 2017: pars 383-387. 
within the ambit of a justification ground (such as, for example, private defence, necessity, superior orders or consent), or be something that the accused is entitled to do in terms of the law of property or the provisions of a statute. ${ }^{27}$ Secondly, it must cause damage, which incorporates any injury to property - including property with mere sentimental value - only limited by the application of the de minimis non curat lex rule. ${ }^{28}$ The concept of damage for the purposes of the crime includes tampering with property in such a way as to require some cost or effort to restore it to its original form..$^{29}$ Thirdly, the damage must be inflicted on property. In this regard, it is clear that the property, whether movable or immovable, must be corporeal in nature, and must not be a res nullius. ${ }^{30}$ The controversy in respect of this element has arisen in the context of whether the crime can ever be committed in relation to a res sua: can one ever be held criminally liable for malicious injury to one's own property? As Snyman correctly points out, in principle this appears indefensible, ${ }^{31}$ given that an owner is entitled to dispose of her property as she chooses. However, on the basis of the 1913 case of $R v$ Gervais, it has been concluded that liability for damage to one's own property might follow where the purpose of damaging the property was to claim its value from the insurance company. ${ }^{32}$ Fourthly, the harm must be committed intentionally. As indicated above, it is not required that the intention be in any way qualified ("malicious"), and consequently this requirement can be satisfied by any form of intention, whether direct intention, indirect intention or dolus eventualis. ${ }^{33}$

\section{Defining arson}

The crime of arson ${ }^{34}$ may be defined as "unlawfully setting an immovable structure on fire with intent to injure another". ${ }^{35}$ Snyman defines arson as being committed where a person unlawfully and intentionally sets fire to (i) immovable property belonging to another or (ii) to his own immovable insured property, in order to claim the value from the insurer. ${ }^{36}$ However, as will be noted below, Snyman's definition does not encompass the authoritative ambit of the crime as set out in the recent Supreme Court Appeal decision of $S v$ Dalindyebo. ${ }^{37}$ A further definitional

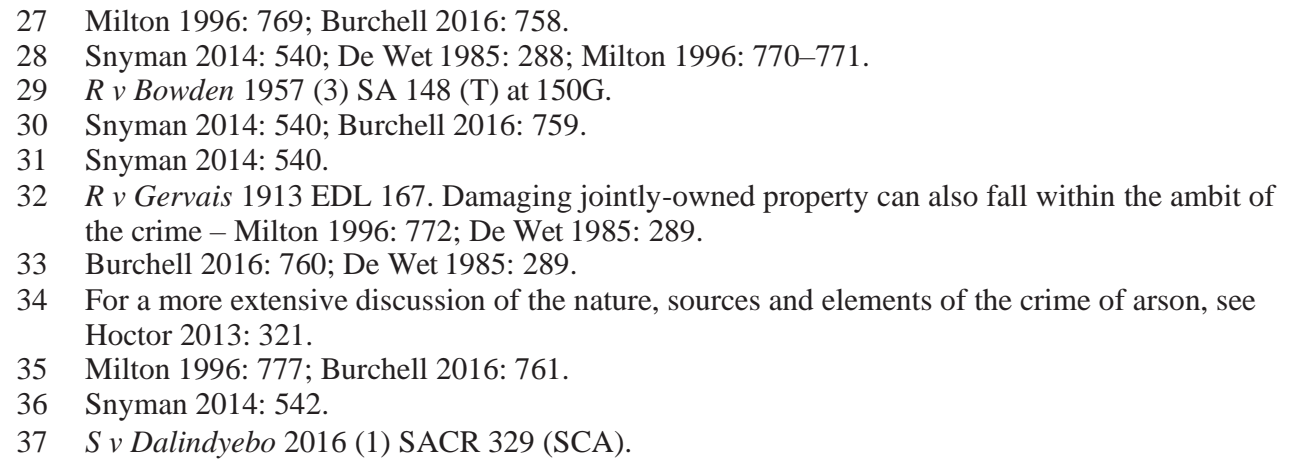


option is that arson is committed "where $\mathrm{X}$ unlawfully and intentionally sets fire to the immovable property of $\mathrm{Y}$, or to the immovable property of $\mathrm{X}$ in which $\mathrm{Z}$ has an interest". ${ }^{38}$ This definition is also deficient in certain aspects, as will be discussed below.

Despite the variation in definition, there is unanimity among scholars regarding the elements of the crime of arson (although there is not complete agreement as to the content of each of these elements). These constituent parts of the crime may be briefly listed. First, there must be a setting on fire. With regard to this element, the structure must actually be set on fire, and some part of the structure must burn and be damaged by the burning, even if the damage is slight. ${ }^{39}$ It follows that damage caused by the smoke emanating from the burning does not suffice for liability for this crime. ${ }^{40}$ Secondly, such burning must be of immovable property. The category of immovable property is not limited to buildings, and can include other forms of immovable property, such as, for example, a field of unharvested grain. ${ }^{41}$ Burchell expresses doubt that immovable property other than buildings (whether used for habitation or storage of property) will indeed be held to fall within the ambit of the crime in South African law, ${ }^{42}$ although he cites no case authority for this view. Thirdly, the setting on fire must be unlawful, that is, there must be no justification ground or statute that excludes the unlawfulness of the conduct. ${ }^{43}$ Fourthly, mere negligence does not suffice for the crime. In order for liability to be established, the accused must have the necessary intention: he must intend to set the structure on fire, and he must intend to cause proprietary injury to another by means of the burning. ${ }^{44}$ Such proprietary injury has typically been characterised as either the direct injury to another's immovable property by burning, or the claim of the value of the damage inflicted on his own insured property from the insurance company. ${ }^{45}$

Recent developments in case law have further clarified the ambit of the crime of arson. In the recent case of $S v$ Dalindyebo, ${ }^{46}$ the Supreme Court of Appeal was required to hear an appeal relating, inter alia, to convictions on three counts of arson (relating to three dwellings) in the High Court. The appellant, the then paramount chief of the AbaThembu tribe, argued in respect of two of the arson counts that the

38 Kemp et al 2018: 457.

39 Milton 1996: 782; Snyman 2014: 542.

40 Burchell 2016: 763.

41 De Wet 1985: 294; Snyman 2014: 542; and, inter alia, the Appellate Division cases of $R v$ Mavros $1921 \mathrm{AD} 19$ at 21-22 and $R v$ Mabula $1927 \mathrm{AD} 159$ at 161.

42 Burchell 2016: 763. Milton 1996: 784 apparently agrees with Burchell that this may well be the position in terms of South African practice, although he proceeds to state that if this is the case, it is "unnecessarily restrictive" (at 785).

43 Milton 1996: 781.

44 Snyman 2014: 542; Milton 1996: 786; De Wet 1985: 294; see, also, $R v$ Kewelram 1922 AD 213.

45 As in $R v$ Mavros $1921 \mathrm{AD} 19$.

$46 \quad S v$ Dalindyebo 2016 (1) SACR 329 (SCA). 
incidents of the burning of the houses, after removal of the complainants' personal belongings, were not simply a crude form of eviction, but took place at the behest of the community, which had taken severe umbrage at the wrongful conduct of the complainants. ${ }^{47}$ Whilst the appellant admitted setting fire to these two houses ${ }^{48}$ he claimed that he was not involved in the conduct implicated in the third count of arson. ${ }^{49}$

Despite the appellant's argument that, since the two houses set on fire were his own property, he could not be convicted of arson, ${ }^{50}$ he was not only convicted on these counts, but also on the third count, on the basis of the available evidence. ${ }^{51}$ The trial court's rationale for this finding was that not only could the eviction by burning not be linked to a community decision, ${ }^{52}$ but further, in the light of the right to housing contained in the Constitution, ${ }^{53}$ along with the decision of the Appellate Division in $S v$ Mavros,${ }^{54}$ a person could be guilty of arson upon setting fire to his or her own property with the intent to injure the interests of another person. ${ }^{55}$

On appeal, the Supreme Court of Appeal examined the defence raised by the appellant, namely that the destruction of one's own property does not amount to arson, and that the burned structures had acceded to the land owned by the appellant, thus confirming his ownership. ${ }^{56}$ The court held that in the role of hereditary monarch the appellant exercised his title on behalf of and for the benefit of his subjects and his tribe, and that a proper understanding of the crime of arson allowed for only one conclusion: that the appellant had acted contrary to the law. ${ }^{57}$ The court came to this finding, having examined ${ }^{58}$ the cases of $R v$ Hoffman; $R v$ Saachs \& Hoffman $n^{59}$ and $R$ $v$ Mavros,${ }^{60}$ as well as the views of Milton ${ }^{61}$ and Hoctor, ${ }^{62}$ and held that "one can be guilty of arson when one wrongfully and/or maliciously sets fire to one's own immovable property, either with the intention to injure another person or to defraud

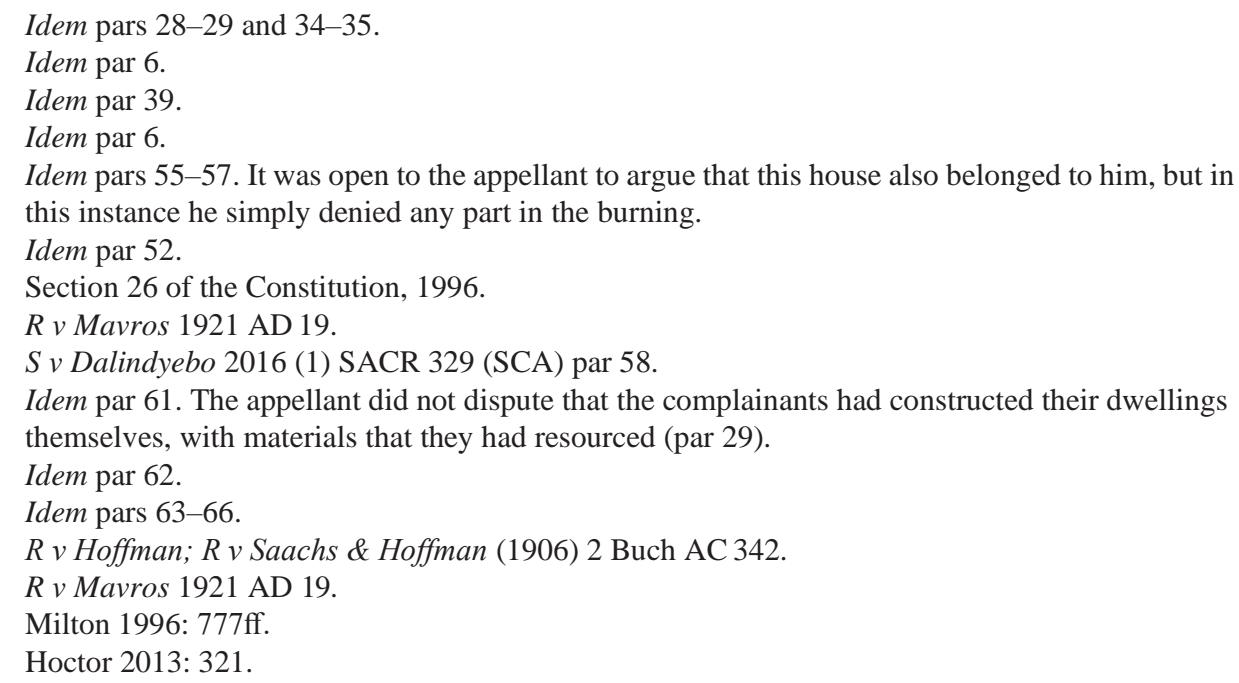


another person". ${ }^{63}$ The convictions on the three counts of arson were consequently confirmed. ${ }^{64}$

The Dalindyebo judgement confirms or clarifies a number of aspects of the crime of arson. First, the court confirmed the importance of the accused's intention in the commission of arson. While the act of destroying one's own property by fire may not be unlawful in itself, the intention with which the accused acts may transform an ostensibly lawful act into an unlawful act. ${ }^{65}$ Similarly, in the crime of extortion, a lawful act may become unlawful, where the accused's intention is unlawful. Thus, for example, in the case of $R v K{ }^{66}$ a policeman was convicted of extortion for suggesting to the complainant, who was being arrested for being involved in illegal gambling, that it would be better to pay a smaller sum of money at that point, than a larger sum at the police station. The complainant paid the smaller sum mentioned by the policeman, and the policeman was held to have extorted the money. As Milton states, the exercise of the pressure in extortion must be unlawful, and this means that "it must be unlawful to use that pressure for the purpose for which X uses it" ${ }^{67}$ Where the unlawful purpose is established, it is of no consequence that the act threatened is something that the accused has, in law, the power to do. ${ }^{68}$ In the same way, where the accused burns his own property, but either foresees the possibility of physical harm to others, or does so with a view to claiming insurance, the crime of arson is committed.

Secondly, the judgement confirms that the crime can be committed by burning down one's own immovable structure with the intention of claiming the value from insurance. It seems that this aspect of the crime derives from English law, specifically section 3 of the Malicious Damage Act of 1861, at least on the basis that this provision established liability where a person set fire to a house or building with intent to injure or defraud ${ }^{69}$ There are no traces of this aspect of the crime in Roman-Dutch law, and Innes CJ's extension of the crime in Mavros, by way of reliance on writers who emphasise that the crime exists to punish those with the intent to prejudice another by burning any building, has been criticised by De Wet in particular, as "a forced and unjustified interpretation of what the writers said" 70 in order to bring South African law in line with the English law. ${ }^{71}$ However, the Supreme Court of Appeal has authoritatively confirmed the approach adopted in Mavros.

$63 S v$ Dalindyebo 2016 (1) SACR 329 (SCA) par 64.

64 Idem par 66.

65 This accords with the dictum in $R v$ Mavros 1921 AD 19 at 22, namely that "the essence of the crime is the intent with which the act is committed".

$66 \quad R v K 1956(2) \mathrm{SA} 217$ (T).

67 Milton 1996: 687.

$68 R v N 1955(2) \mathrm{SA} 647(\mathrm{~T})$ at $652 \mathrm{H}$.

69 Milton 1996: 785.

70 The original text: "'n [G]eforseerde en ongeregverdigde uitleg van wat die skrywers gesê het."

71 De Wet 1985: 294. See, also, Snyman 2014: 542, who agrees that it is better to punish such conduct as fraud, rather than as arson. 
Thirdly, the Dalindyebo judgement establishes a new perspective on the crime of arson. Whereas arson has always been categorised as a crime against damage to property ${ }^{72}$ or human habitation, ${ }^{73}$ the clarification of the ambit of the crime in Dalindyebo means that it also encompasses the protection of the interests of the community. As noted, arson has previously been seen as merely a species of malicious injury to property, which has led to its independent existence as a crime being called into question. ${ }^{74}$ However, the court's confirmation that the crime can be committed in respect of one's own property - where the accused at least foresees the possibility that in setting the fire damage could result to another's property, and continues in his course of conduct - distinguishes this crime from malicious injury to property, which, by definition, ${ }^{75}$ involves damaging the property of another ${ }^{76}$

\section{The historical development of malicious injury to property}

The destruction of property was punished in terms of the Lex Aquilia as damnum injuria datum, a delictum privatum. ${ }^{77}$ Thus, damage to property could give rise to a civil action aimed at damages, while still retaining a criminal aspect; the Lex Aquilia being partly penal and partly reipersecutory. ${ }^{78}$ However, it seems that the actio legis Aquiliae was losing its penal character by the time of Justinian, and unlike other delicta privata, damnum injuria datum never developed into a crimen extraordinarium. ${ }^{79}$ Milton states that vis was the most important Roman law antecedent for the crime of malicious injury to property, "for texts dealing with the lex Julia de vi make it clear that many cases of malicious injury to property were dealt with under that statute". ${ }^{80}$ In making this assessment, Milton refers ${ }^{81}$ to the cases of JJ Raw v Clerk of Peace, Pietermaritzburg County ${ }^{82}$ and AJ Bruyns $v$ Regina ${ }^{83}$ as well as referring to D 486 , entitled Ad Legem Iuliam de vi publica (with regard to the Lex Julia on vispublica).

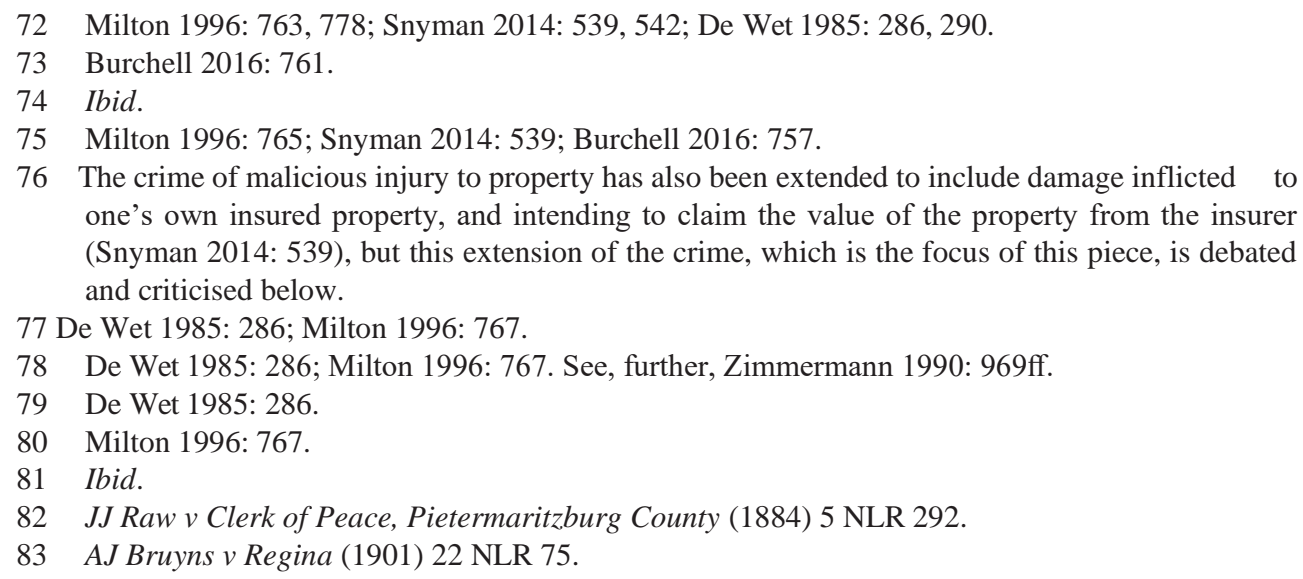


The Raw case arose out of the shooting of a dog at the house of the complainant, and the court unhesitatingly classified the charge as one of "violence", given that "all use of arms or weapons for spoliation of property, seems to, be included under this head". ${ }^{84}$ It is, however, clear that not all instances of malicious injury to property are related to the use of a weapon, and it is consequently doubtful whether vis is indeed the most likely antecedent of malicious injury to property. In the Bruyns case, the court affirmed that the cutting down of a fence does indeed amount to a crime, as "such an act comes within the Roman Law definition of the crime of violence" ${ }^{85}$ However, it is by no means clear that this statement is correct. The conduct that is described in D 486 (relating to public violence) and D 487 (relating to private violence ${ }^{86}$ certainly has application to the common-law crime of public violence, ${ }^{87}$ along with, inter alia, robbery ${ }^{88}$ or even arson, where this is committed by a group of people. ${ }^{89}$ However, there is no indication that destruction of property that does not occur violently, falls within the ambit of criminal liability for vis. ${ }^{90}$

In the light of the fact that vis does not appear to provide a general foundation for the crime of malicious injury to property, it is submitted that the better approach is that favoured by De Wet, which avers that while there was no crime of malicious injury to property as such in Roman law, the earliest antecedents for this crime are based on the Lex Aquilia. ${ }^{91}$ The absence of a clear crime dealing specifically with intentional damage to property in Roman law not unexpectedly gave rise to the lack of such a crime in Roman-Dutch law. ${ }^{22}$ Instead, it seems that the "conception of the crime as known in English law" was introduced into South African law through the decided cases, ${ }^{93}$ and that the emergence of the crime can be traced to case law, rather than to any common-law source. The English authority in question, undoubtedly influential though generally unacknowledged, took the form of the Malicious Damage Act of $1861,{ }^{94}$ "a rather primitive piece of legislation which penalized

84 JJ Raw v Clerk of Peace, Pietermaritzburg County (1884) 5 NLR 292 at 293.

85 AJ Bruyns v Regina (1901) 22 NLR 75 at 77.

86 Robinson 1995: 29 makes the point that the problem with the Digest is to decide why the compilers produced two titles, but then "failed to differentiate between the two concepts".

87 See Milton 1996: 73.

88 D 48635.

$89 \mathrm{D} 4865 \mathrm{pr}$.

90 See $R v$ Ndaba 1942 OPD 149 at 153. Moreover, Van den Heever J points out that cases of vis typically involved concerted action by a crowd. Once again, such conduct may result in liability for malicious injury to property, but this would not be a necessary feature of the crime.

91 See, also, $R$ v Maruba 1942 OPD 51 at 54 for further support for this view.

92 Idem at 55; S v Solomon 1973 (4) SA 644 (C) at 648A-C; Milton 1996: 767; De Wet 1985: 287287. Hence, it may be submitted, the reliance by the court in Queen v Reikert (1874) 4 Buch 142 on Matthaeus 473 is misplaced, for, as De Wet 1985: 287 points out, this work simply refers to a number of instances where criminal liability could follow for damage to property, rather than establishing that intentional damage to property was generally regarded as criminal.

$93 R v$ Maruba 1942 OPD 51 at 55.94

(24 \& 25 Vict c 97). 
numerous ways of causing damage "unlawfully and maliciously". ${ }^{95}$ The prolixity of this Act is evident in its attempt to include all manner of damage within its scope. The acts of damage criminalised in this statute included setting fire to all manner of buildings or goods therein; ${ }^{96}$ causing damage to buildings or goods therein by explosive substances $;{ }^{97}$ causing damage to buildings or machinery in the course of a riot; ${ }^{98}$ causing of damage to buildings by tenants; $;{ }^{99}$ destruction of machinery or goods in the manufacturing process; ${ }^{100}$ causing damage or destruction to corn, trees and vegetable productions; ${ }^{101}$ damaging fences; ${ }^{102}$ setting fire to or causing damage in a mine; ${ }^{103}$ causing damage to sea or river banks, or to fixtures on canals or rivers; ${ }^{104}$ causing damage to ponds; ${ }^{105}$ causing damage to bridges, viaducts and toll bars; ${ }^{106}$ causing damage to railway carriages and telegraphs; $;{ }^{107}$ causing damage to works of art; ${ }^{108}$ causing damage to cattle or other animals; ${ }^{109}$ setting fire to or damaging ships; ${ }^{110}$ sending letters threatening damage; ${ }^{111}$ making gunpowder to commit offences; ${ }^{112}$ and causing any other damage not already specifically mentioned in the Act. ${ }^{113}$ It is clear that the Act encompasses the conduct criminalised in the South African common-law crimes of arson and malicious injury to property.

It is particularly noteworthy that the Act specifically extended the criminalisation of the burning and other damage caused, to include damage caused with the intent to defraud another person. The Act specifically provides for this in relation to the

95 Milton 1996: 767-768.

96 Sections $1-8$.

97 Sections 9-10.

98 Sections 11-12.

99 Section 13.

100 Sections $14-15$.

101 Including setting fire to crops or stacks of corn (ss 16-18); destroying hopbinds (s 19); destroying trees and shrubs (ss 20-22); and destroying fruit and vegetables (ss 23-24). See, also, s 53 (damage to trees).

102 Section 25.

103 Sections 26-29.

104 Sections 30-31. The obstruction of navigation is also targeted in these provisions.

105 Section 32.

106 Sections 33-34.

107 Sections 35-38.

108 Section 39.

109 Sections 40-41.

110 Including setting fire to a ship (s 42); setting fire to a ship so as to prejudice the owner or underwriter (s 43); attempting to set fire to a vessel (s 44); placing gunpowder near a vessel with intent to damage it (s 45); damaging ships otherwise than by fire (s 46); exhibiting false navigational signals (s 47); removing or concealing buoys or other sea marks (s 48); and destroying wrecks or any articles belonging thereto (s 49).

111 Section 50.

112 Section 54.

113 Sections 51-52. 
setting on fire of a house or other building listed in section $3,{ }^{114}$ and in relation to the setting on fire of a ship or vessel in section 43 , by specifically referring to insurance underwriters. ${ }^{115}$ Moreover, and importantly for the crime of malicious injury to property, the Act specifically extended its protection to persons who are in possession of the property that they damage, and who act with either intent to injure or defraud: ${ }^{116}$

Every Provision of this Act not herein-before so applied shall apply to every Person who, with Intent to injure or defraud any other Person, shall do any of the Acts herein-before made penal, although the Offender shall be in possession of the Property against or in respect of which such Act shall be done.

It was further provided that an intent to injure or defraud particular persons need not be stated in any indictment. ${ }^{117}$

While the existence of the crime of malicious injury to property was acknowledged by South African courts from at least the first half of the nineteenth century, ${ }^{118}$ an

114 "Whosoever shall unlawfully and maliciously set fire to any House, Stable, Coach-house, Outhouse, Warehouse, Office, Shop, Mill, Malthouse, Hop-oast, Barn, Storehouse, Granary, Hovel, Shed, or Fold, or to any Farm Building, or to any Building or Erection used in farming Land, or in carrying on any Trade or Manufacture or any Branch thereof, whether the same shall then be in the Possession of the Offender or in the Possession of any other Person, with Intent thereby to injure or defraud any Person, shall be guilty of Felony, and being convicted thereof shall be liable, at the Discretion of the Court, to be kept in Penal Servitude for Life or for any Term not less than Three Years, - or to be imprisoned for any Term not exceeding Two Years, with or without Hard Labour, and with or without Solitary Confinement, and, if a Male under the Age of Sixteen Years, with or without Whipping" (emphasis added).

115 "Whosoever shall unlawfully and maliciously set fire to, or cast away, or in anywise destroy any Ship or Vessel, with Intent thereby to prejudice any Owner or Part Owner of such Ship or Vessel, or of any Goods on board the same, or any Person that has underwritten or shall underwrite any Policy of Insurance upon such Ship or Vessel, or on the Freight thereof, or upon any Goods on board the same, shall be guilty of Felony, and being convicted thereof shall be liable, at the Discretion of the Court, to be kept in Penal Servitude for Life or for any Term not less than Three Years, - or to be imprisoned for any Term not exceeding Two Years, with or without Hard Labour, and with or without Solitary Confinement, and, if a Male under the Age of Sixteen Years, with or without Whipping."

116 Section 59.

117 In terms of s 60: "It shall be sufficient in any Indictment for any Offence against this Act, where it shall be necessary to allege an Intent to injure or defraud, to allege that the Party accused did the Act with Intent to injure or defraud (as the Case may be), without alleging an Intent to injure or defraud any particular Person; and on the Trial of any such Offence it shall not be necessary to prove an Intent to injure or defraud any particular Person, but it shall be sufficient to prove that the Party accused did the Act charged with an Intent to injure or defraud (as the Case may be)."

118 As noted above, the Attorney General stated in Queen v Reikert (1874) 4 Buch 142 at 143 that indictments had been laid and convictions obtained in the Cape Colony since 1837 . The indictment was upheld in this case. The existence of the crime was further confirmed in other nineteenthcentury judgements, namely in the Cape in the case of Queen v Enslin (1885) 2 Buch AC 69 at 71; in the Eastern Districts in Queen v Johannes (1880-1881) 1 EDC 93; in Natal in JJ Raw v Clerk of Peace, Pietermaritzburg County (1884) 5 NLR 292; and in the Transvaal in Gourlie \& Verkouteren $v$ The State (1896) 3 Off Rep 68. 
authoritative definition of the crime was first stated in the Appellate Division decision of $R v$ Mashanga, where the crime was described as the "intentional wrongful injury to the property of another". ${ }^{119}$ This definition was followed in numerous cases thereafter, ${ }^{120}$ and is still authoritative today. ${ }^{121}$ Indeed, as reflected earlier, it forms the basis of the definition employed in all the leading texts. ${ }^{122}$ How then did it come to be that the definition of the crime of malicious injury to property has been extended to include causing damage to one's own insured property, with the intent to claim the value of the damage from the insurer?

The basis for this development may be found in $R v$ Gervais, ${ }^{123}$ decided in the Eastern Districts Local Division about a decade before the Appellate Division decision in Mashanga. The accused was charged with malicious injury to property, on the basis that he had set on fire a wood-and-iron structure, which he used as a café, with the intent of burning the structure, and with the further intent "to defraud a certain insurance company". Counsel for the accused excepted to the indictment on the grounds that the facts alleged did not constitute the crime charged, as there could be no malicious injury to one's own property where the harm was self-inflicted. ${ }^{124}$ It was noted by counsel for the accused that there was authority for the burning of one's own property to constitute arson, and that the case of Hoffman ${ }^{125}$ - which related to arson - did indeed involve the application of the crime to an insurance claim. ${ }^{126}$ It is evident that counsel was putting to the court that, whatever the position was in respect of arson, the charge before the court related to malicious injury to property, where there was no authority to similarly expand the ambit of the crime. The recorded response of Sheil J in the judgement seems instructive: referring to the case of Queen $v$ Enslin, ${ }^{127}$ the judge remarked that "[i]f the indictment in this case had been for arson, exception would probably have been taken to that also". With respect, this does not address counsel's argument at all. The Enslin case turned on the fact that the court did not regard the accused's burning of stacks of barley belonging to the complainant as arson, as it was held that the stacks of barley could not be

$119 R v$ Mashanga $1924 \mathrm{AD} 11$ at 12.

120 See, for example, $R v$ Blore 1934 OPD 62 at 63; Woodburn $v$ Rex 1944 NPD 1 at 2; $R v$ Mandatela 1948 (4) SA 985 (E) at 991; $R$ v Ncetendaba 1952 (2) SA 647 (SR) at 650H; $R$ v Bhaya 1953 (3) SA $143(\mathrm{~N})$ at 148F-G; $R$ v Pope 1953 (3) SA 890 (C) at 894D-E; $R v$ Mohale 1955 (3) SA 563 (O) at 564D-E; $R v$ Maritz 1956 (3) SA $147(\mathrm{GW})$ at 151F; $R v$ Bowden 1957 (3) SA 148 (T) at 150B-C; $R v$ Mtshilselwe 1957 (3) SA 313 (E) at 314H; $S v$ Kgware 1977 (2) SA 454 (O) at 455D-E.

121 De Wet 1985: 287-288; Milton 1996: 765; Snyman 2014: 539.

122 See n 23 supra.

$123 R v$ Gervais 1913 EDL 167.

124 Idem at 168.

$125 R v$ Hoffman; $R v$ Saachs \& Hoffman (1906) 2 Buch AC 342.

$126 R v$ Gervais 1913 EDL 167 at 168

127 Queen v Enslin (1885) 2 Buch AC 69, cited in Rv Gervais 1913 EDL 167 at 168. 
regarded as immovable property (or a house) for the purposes of an arson conviction. The court in Enslin held that the appropriate indictment was one of malicious injury to property, which it later held that the accused could be charged with. ${ }^{128}$ Whether exception would have been taken to a charge of arson on the facts before the court in Gervais is not of any consequence, and is merely of academic interest. The question is whether the facts of the present case constituted the crime of malicious injury to property. Nevertheless, without prosecuting counsel being called upon, and without any citation of any authority, Sheil J ruled, in a single-sentence judgement, that the exception must in his opinion be overruled, although his possible recognition of the somewhat tenuous basis for the ruling is reflected in the statement that "the point will be reserved in case of conviction for the consideration of the Court of Criminal Appeal". ${ }^{129}$ The accused was, however, acquitted, ${ }^{130}$ and so there was no need to revisit the question of the extension of the ambit of the crime of malicious injury to property.

As the synopsis of the judgement makes plain, there is no significant precedent created by the Gervais decision, at least not in respect of the crime of malicious injury to property. The judgement in Gervais has, however, been cited as authority for the proposition that in order for a conviction for arson to ensue, the property that has been burnt must be immovable, ${ }^{131}$ and that "a movable structure can in everyday parlance be a building". ${ }^{132}$ In the first edition of Gardiner and Lansdown, ${ }^{133}$ the Gervais judgement was cited as authority for the proposition that the burning of movable property does not constitute arson, ${ }^{134}$ and as authority for the proposition that where damage is done to his own insured property by the accused, who subsequently claims from the insurer, this could constitute arson (where the damage is done by burning). ${ }^{135}$ The judgement is cited in relation to the same propositions in the sixth and final edition of this work, once again in the context of arson. ${ }^{136}$ Writing in 1949, De Wet and Swanepoel discuss Gervais in the context of malicious injury to property, but are extremely critical of the effect of the court overruling the exception: that the

128 Queen v Enslin (1885) 2 Buch AC 119.

$129 R v$ Gervais 1913 EDL 167 at 168

130 Ibid.

$131 S v$ Motau 1963 (2) SA 521 (T) at 522H. The Gervais decision also arose in argument before the Appellate Division in $R v$ Mavros 1921 AD 19 and in $R v$ Mabula 1927 AD 159, although it was not mentioned in the judgements of these cases, which both dealt with appeals against convictions for arson. Similarly, the Gervais decision was mentioned in argument, but not the judgement, in $R v$ Paizee 1916 SR 130.

$132 R$ v Innocent $1966(2) \mathrm{SA} 362(\mathrm{R})$ at $363 \mathrm{~F}-\mathrm{G}$.

133 Gardiner \& Lansdown 1919: passim.

134 Idem at 1163.

135 Idem at 1165.

136 Lansdown, Hoal \& Lansdown 1957: 1780, 1783 respectively. 
ambit of the crime would be expanded to include damage to one's own property along with an insurance claim. ${ }^{137}$

The Gervais judgement was, however, cited in one case that dealt exclusively with malicious injury to property, namely the 1963 Natal case of $S v$ Mtetwa. ${ }^{138}$ The court reasoned, citing Gardiner and Lansdown, that, for a conviction of malicious injury to property, "it is not necessary that the complainant should be the full and unencumbered owner of the property injured", but that what is required "is that the intentional and unlawful act be an injury to the rights of another person in and to that property". ${ }^{139}$ The citation from Gardiner and Lansdown relates to the proof of the intent requirement for this crime, ${ }^{140}$ rather than seeking to define the ambit of the crime. ${ }^{141}$ The court then proceeded to cite the Gervais case as authority for the proposition that "[j] ust as a person may be guilty of theft of property of which he is owner (e.g. of pledged property belonging to him) so too he may be guilty of malicious injury to property of which he is, in law, the owner but in which other persons have rights". ${ }^{142}$

The court (per Harcourt J) relied on two further cases in support of this approach. ${ }^{143}$ In Kohrs $v$ Rex, the accused was convicted of malicious injury to property where he set three huts alight, even though there was no proof that the huts were owned by the complainant. ${ }^{144}$ Harcourt J cited the statement of the court ${ }^{145}$ (per Jarvis AJ) to the effect that "property" is capable of covering "physical objects as well as rights of all kinds in and to physical objects". This statement is, however, not bolstered by reference to any sources, or further elaborated upon. The cited statement

137 De Wet \& Swanepoel 1949: 323-324 argue that this approach is clearly wrong, and that it constitutes indefensible reasoning - the fact that property is insured does not entail that it belongs to someone else. Moreover, they reason, even if, for example, one kills one's own insured cattle, that in itself cannot be malicious injury to property. A later insurance claim may well be criminal, but then on the basis of fraud. These arguments are carried through to the fourth and last edition of this work - see De Wet 1985: 288-289.

138 S v Mtetwa 1963 (3) SA $445(\mathrm{~N})$.

139 Idem at $449 \mathrm{D}-\mathrm{E}$.

140 "Where, from the nature of an intentional and unlawful act, it would appear to any reasonable person doing it that its result would be injury to the rights of another person, the court will infer that the accused contemplated such injury and therefore that the act was done intentionally" (Lansdown, Hoal \& Lansdown 1957: 1786). Whilst it bears noting en passant that this statement is, in itself, problematic, this has no bearing on the present argument.

141 In fact, Lansdown, Hoal \& Lansdown (1957: 1784) indicate that the term "injury" bears a restricted meaning, and does not encompass every infringement of a right. They state that the meaning of injury ("the loss or destruction of ... property") "is obviously distinct from that wider sense in which the word is used in law to denote an unlawful infringement of a right".

142 S v Mtetwa 1963 (3) SA $445(\mathrm{~N})$ at 449E-F.

143 Idem at $449 \mathrm{~F}-\mathrm{H}$.

144 Kohrs v Rex 1940 NPD 11.

145 Idem at 14. 
of Jarvis AJ continued, indicating that "property" includes "any goods which may reasonably be believed to be in that structure", ${ }^{146}$ before asserting that it was not in dispute that the appellant "had good grounds for believing that there was personal property of the complainant in one or more of the huts". ${ }^{147}$ Hence the presence of the personal property was apparently deemed probative of the complainant having some right, albeit unspecified, over the huts. The second case, Njokweni $v$ Rex ${ }^{148}$ held that the accused could be convicted of malicious injury to property for damaging his customary-law wife's personal property. Despite the general custom that women were incapable of private ownership, it was held that customary law could recognise that the "personal wearing apparel" of the wife could be regarded as her own property.

The conviction in Mtetwa was confirmed on the basis that the cattle destroyed by the accused were the personal property of the complainant, ${ }^{149}$ although the court added, perhaps ex abundanti cautela, that even if this were not so, the rights that the complainant had in the property were sufficient to found a conviction of malicious injury to property based on the killing of the cattle. ${ }^{150}$ The approach apparently adopted in Gervais - to accord protection in terms of the crime of malicious injury to property to the rights of an insurer - can, it is submitted, be distinguished from the Mtetwa case and the cases cited therein that deal with this question. In none of these cases did the damaged or destroyed property belong to the accused: the accused in Kohrs was merely a lessee of the farm on which the destroyed huts were situated; ${ }^{151}$ the personal property in question in the Njokweni case was held to belong to the complainant in terms of customary law; and the claim by the accused in Mtetwa to have rights to the cattle he destroyed were firmly rejected by the court. ${ }^{152}$

Could it nevertheless be argued that the crime of malicious injury to property protects rights other than ownership, such that the crime can be committed by the owner in respect of his own property? It is submitted that, just as with theft, ${ }^{153}$ the crime of malicious injury to property is committed by the owner in relation to his own property, provided that the complainant who is in possession of the property has a right of retention over the property. The rationale for this, as with furtum

146 Idem at $14-15$.

147 Idem at 15.

148 Njokweni $v$ Rex 1946 NPD 400. The correctness of this decision was doubted in $S v$ Swiegelaar 1979 (2) SA 238 (C).

$149 S v$ Mtetwa 1963 (3) SA 445 (N) at 451D-E. The court further remarked that the witnesses in the case all accepted in terms of local custom that the cattle had passed into the ownership of the complainant (at $451 \mathrm{H})$.

150 Idem at $451 \mathrm{G}-\mathrm{H}$.

151 Kohrs $v$ Rex 1940 NPD 11 at 13

152 The court further held that not only did the accused not have any right to the cattle, but it was quite clear that he knew that he did not have any such right ( $S$ v Mtetwa 1963 (3) SA $445(\mathrm{~N})$ at $452 \mathrm{C}-\mathrm{G})$.

153 Snyman 2014: 492; Milton 1996: 604. 
possessionis, is that "[o]ur criminal law, intended to preserve order and keep the peace, cannot allow de facto possession to be disturbed with impunity except by one who himself has a claim as of right against the possessor". ${ }^{154}$ It follows that, just as "where possession or custody is accompanied by some interest or right to retain such as against the person depriving the possessor or custodian of such possession or custody, the unlawful deprivation amounts to theft", ${ }^{155}$ the same rationale would apply to the violation of the possessory right of the complainant where the owner damages his own property.

This conclusion accords with the statement in Mtetwa (cited above) drawing an analogy between theft of pledged property that belongs to him and a conviction for malicious damage to property by an owner of property "in which other persons have rights". However, while Gervais is cited in support of this proposition, the rights contemplated and protected in the crimes of theft and malicious injury to property are real rights, predicated on the unlawful interference in the possession of the complainant, who by virtue of, at least, a right of retention, is entitled to enforce his right against anyone else, including the owner. ${ }^{156}$

On the other hand, the right of the insurer is a personal right, enforceable against the insured party, and based on the contractual relationship between the insurer and the insured party. While the insurer's right of salvage in the case of total loss of the insured property amounts to a real right, ${ }^{157}$ it seems clear that at the point at which liability is assessed in terms of the extension of the ambit of malicious injury damaging one's own insured property with the intent to claim its value from the insurer - there is no question of a real right on the part of the insurer. In short, the crime of malicious injury to property does not encompass the protection of "rights of all kinds in and to physical objects", as per the dictum in Kohrs (cited above), but rather the injury to the rights of another person to the property in question must, in accordance with the analogous rationale and practice of the law of theft, be limited to real rights. As reflected in the law of theft, there is a key difference between actually depriving a person of his or her control over property and the violation of someone's personal right in terms of a contract. Gervais cannot be supported on this basis.

In the case of $S v M n y a n d u,{ }^{158}$ a further definition of malicious injury to property was offered, namely the unlawful and intentional damaging of a thing belonging to somebody else or in which another person has a substantial interest. ${ }^{159}$ While the first part of the definition derives from $R v$ Mashanga, which is cited as a source in

$154 R v$ Twala 1952 (2) SA 599 (A) at 606.

$155 R v$ Rudolph 1935 TPD 79 at 84.

156 See the discussion, in the context of furtum possessionis, in $R v$ Janoo 1959 (3) SA 107 (A) at $110-112$.

157 On the right of salvage, see Reinecke, Van Niekerk \& Nienaber 2013: pars 84-87.

158 S v Mnyandu 1973 (4) SA SA $603(\mathrm{~N})$.

159 This is the translation provided in the headnote of the case of the dictum, in Afrikaans, at 606A: "[D]ie wederregtelike en opsetlike beskadiging van 'n saak van iemand anders of waarin 'n ander 'n wesenlike belang het." The author in Kemp et al 2018: 456 favours this definition. 
the text, ${ }^{160}$ the court does not indicate the source for the extension of the Mashanga definition, so as to include within the crime damage to property in which another person has a "substantial interest". It is submitted that this definition can best be clarified and contextualised within the framework of the protection afforded the possessor who holds a ius retentionis over property, and thus that the reference to a "substantial interest" should refer to the holder of such a possessory right.

Even though Gervais is not consistent with this approach, it is evident that, despite De Wet and Swanepoel's disdain for the approach adopted there, the majority academic view is that the ambit of the crime of malicious injury to property has been expanded to include damaging one's own property with a view to claiming its value from the insurer. Following De Wet and Swanepoel's concerns, in 1970, Hunt concluded that, on the basis of the Gervais decision, and on the basis that the courts are "unlikely to differ from the rule which applies in arson", the definition of malicious injury to property must be taken to have been expanded. ${ }^{161}$ While critical of this development, Snyman agrees that the definition has been expanded, for the same reasons set out by Hunt. ${ }^{162}$ Both Burchell ${ }^{163}$ and Milton ${ }^{164}$ acknowledge the authority of the Gervais case, although neither author develops the argument any further. In the absence of any more recent authoritative decision in this regard, this is then the status quo.

\section{The historical development of arson}

Despite there being a number of Roman law texts dealing with fire-setting (incendium) ${ }^{165}$ it is doubtful whether arson was ever regarded as an independent crime with its own characteristics. ${ }^{166}$ It follows that classification of this type of criminal conduct in Roman law is difficult. It is submitted that there is value in Milton's view that arson was considered as an offence against both property and the safety of the community, and was punished severely especially where the arson endangered the community. ${ }^{167}$

160 At 606A, where Lansdown, Hoal \& Lansdown 1957: 1785 and Hunt 1970: 784 were also cited. It seems that all three sources were cited in support of the court's approach to intention, rather than in relation to the definition of the crime.

161 Hunt 1970: 779.

162 Snyman 2014: 540. See, also, Kemp et al 2018: 456-457, who also accepts that the owner of property who inflicts damage to his own property can be liable for the crime in these circumstances. 163 Burchell 2016: 759.

164 Milton 1996: 772 n 75.

165 Some as early as the Twelve Tables - see D 4799.

166 De Wet 1985: 290.

167 Milton 1996: 779. See D $4881 \mathrm{pr}$, where intentional fire-setting, which falls into the category of either danger to property or danger to others, is punished under the lex Cornelia de sicariis. The greater severity of punishment for urban fire-setting is reflected in D 47 9 12, D 48192812 and D 48810 , and the more severe punishment of some types of fire-setting in certain provinces is reflected in D 4819169 . Liability could also follow where a group of persons commited arson in the context of public violence: see D $4865 \mathrm{pr}$. 
Despite the Roman-Dutch writers apparently regarding arson as both a crime against property and as a crime against the community, these dual interests did not result in separate crimes, but rather in one single crime (brandstichting). ${ }^{168}$ However, Carpzovius had a more detailed treatment of brandstichting, where he indicated that there is no distinction between the locality or the type of building for the purposes of liability. ${ }^{169} \mathrm{He}$ further stated that the damage caused by burning need not be extensive to trigger liability; ${ }^{170}$ that the motive for the burning is irrelevant; ${ }^{171}$ and that the crime may be committed by someone who sets his own house on fire intending to prejudice someone else. ${ }^{172}$ Moorman also engaged in a detailed discussion of brandstichting, taking the view that the crime is directed against property. ${ }^{173}$ The crime is complete as soon as damage to the building ensues as a result of the fire, and the extent of the damage is not determinative in respect of liability. ${ }^{174}$ Moreover, Moorman stated that the crime is committed by someone who, in order to prejudice someone else, sets fire to his own house. ${ }^{175}$

Van der Linden classified the crime of brandstichting as a crime against the state, thus highlighting the value of the safety of the community, and defined the crime in the following terms: ${ }^{176}$

This crime is committed when a person with the wilful intention of injuring others, has set fire to buildings or other immovable property, whereby such property has caught fire and damage has been occasioned.

Milton's synopsis of the views of the Roman-Dutch writers is very useful: ${ }^{177}$ that in respect of the crime of brandstichting there had to be intentional fire-setting with the intent to injure another, ${ }^{178}$ that some damage caused by the fire had to be established, ${ }^{179}$ and that even setting fire to one's own house suffices for liability where the accused's

168 Milton 1996: 779. The crime does not receive systematic treatment among writers, with discussion of the elements of the crime often being rather superficial. Writers, such as Voet ad 4795 at 200; Van Leeuwen ad 43810 at 492; Matthaeus 4856 and 4857 14; and Van der Keessel 48825 and 26 , limit their treatment of the crime to the Roman law texts, as well as to the punishment imposed for the offence at the time of writing.

169 Carpzovius ch 35.

170 Idem ch 35 10, indicating that even minimal damage ('zeer geringe schade') will suffice.

171 Idem $\operatorname{ch} 3515.172$

Idem ch 35 11-12.

173 Moorman 317 stated that the crime can be committed in respect of "Huizen, Pakhuizen, Schuren, Wynperssen en diergelyk gebouw".

174 Idem 318.

175 Idem 3110.

176 Van der Linden 247 . The severity of the crime is determined by the locality in which it occurs and the danger that results from it.

177 Milton 1996: 779.

178 Van der Linden 24 7; Van der Keessel 48825.

179 Moorman 31 1, 7 and 8; see, also, Carpzovius ch 3510. 
intention in doing so was to harm another. ${ }^{180}$ While the writers did not agree as to the nature of the property that was protected by brandstichting, Van der Linden's statement that it was required that the burning occur in respect of "buildings or other immovable property" 181 was authoritatively adopted by the Appellate Division. ${ }^{182}$

In Queen v Enslin, ${ }^{183}$ the court refused to entertain the notion that "arson" was equivalent to the Roman law crime of incendium or to the Roman-Dutch law crime of brandstichting, instead adhering to the English common-law conception of the crime. ${ }^{184}$ The case of $R v$ Hoffmann; $R v$ Saachs \& Hoffmann, however, saw the equation of "arson" and brandstichting, and the consequent application of RomanDutch antecedents (instead of English common-law sources, in terms of which the setting on fire of one's own property was not a crime): ${ }^{185}$

Where a person attempts to set fire to the house of another person he is guilty of an attempt to commit arson, whether there is any intent to fraudulently obtain insurance money or not. Where a person burns his own house, the question whether he is guilty of "brandstichting", or arson, must, under our law, depend upon the further question whether the deed was done with the object of injuring others ... If the object be to defraud an insurance company the intent would certainly be to injure another so as to bring the offence within the definition.

By aligning with Roman-Dutch rather than English authority, the court provided for the South African crime to be broadened to include the burning of one's own building in certain circumstances. This indeed took place where an accused was charged with burning down his own building with intent to defraud an insurance company in $R v$ Paizee, ${ }^{186}$ and it was held by the court, approving the dictum in Hoffmann, that he was properly charged with arson. ${ }^{187}$

Shortly thereafter, the Appellate Division, in the case of $R v$ Mavros, was called upon to assess the ambit of the crime of arson. ${ }^{188}$ In this case, similarly to Paizee, a shopkeeper was convicted of arson, in that he set fire to his store with the intention

180 Moorman 31 10; Carpzovius ch 35 11-12.

181 Van der Linden 247.

$182 R$ v Mavros $1921 \mathrm{AD} 19$ at 21-22.

183 Queen $v$ Enslin (1885) 2 Buch AC 69. It was argued before the court that the "malicious burning of the barley stacks of another" constituted arson, given that "arson" in essence shared the content of its common-law antecedents, which would include burning movables, such as barley stacks. Given the lack of unanimity between the common-law sources regarding the type of property included in the crime of arson, the court preferred to rely on the English approach.

184 See the discussion of English law in Milton 1996: 780.

$185 R v$ Hoffmann; $R v$ Saachs \& Hoffmann (1906) 2 Buch AC 342 at 346-347. The court relied on Van der Linden 247 in this regard. The English Malicious Damage Act of 1861 was, however, amenable to this interpretation - see $\mathrm{s} 3$.

$186 R v$ Paizee 1916 SR 130 at 131, where Hopley J takes the view that the crime of arson includes within its ambit the Roman law crime of incendium and the Roman-Dutch crime of brandstichting.

187 Ibid.

$188 \quad R$ v Mavros 1921 AD 19. 
to defraud an insurance company. Innes CJ noted the variability of the Roman-Dutch writers as to whether brandstichting would cover intentionally burning a building with intent to injure or defraud another. ${ }^{189}$ However, Carpzovius ${ }^{190}$ and Moorman ${ }^{191}$ were cited ${ }^{192}$ as authority for the view that brandstichting includes the setting on fire of one's own house with intent to burn one's neighbour's house. The court held that the key aspect for these writers is the intention to injure or destroy the building of another. ${ }^{193}$ The court concluded that given that brandstichting and "arson" are synonymous terms, the accused was correctly convicted of arson. ${ }^{194}$

This matter arose for consideration once again some years later, in the 1987 case

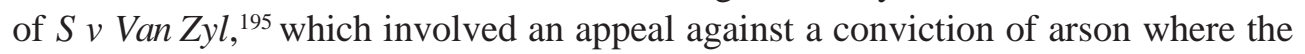
appellant had burnt down a house belonging to himself, which was inhabited by the complainant. The conviction was contested on the basis that the common- law crime of arson did not extend to a person burning down his own immovable property. The court held that Van der Linden's passage cited above was amenable to the interpretation that brandstichting could also be committed where a person, with intent to cause damage to another, sets fire to his own building. ${ }^{196}$ Having examined the judgement in Mavros, and the sources cited therein (notably Carpzovius and Moorman), the court held that it was correctly decided. ${ }^{197}$ The court therefore confirmed that arson can be committed where a person sets fire to his own immovable property with the intention to prejudice the property interests of another person. ${ }^{198}$

189 Idem at 22. Innes CJ notes that a number of writers only dealt with the matter in general terms, referring, inter alia, to Matthaeus, Kersteman and, notably, Van der Linden. However, this was explicable on the basis that fire insurance was yet to come into being, according to the Chief Justice. As the court noted, the English common law of arson would not be applicable to these facts, although an application of the English Malicious Damage Act of 1861 would indeed result in liability (at 21).

190 Carpzovius ch 36

191 Moorman 3110.

$192 R$ v Mavros $1921 \mathrm{AD} 19$ at 22.

193 Idem at 22-23.

194 Idem at 23. Despite the court overtly seeking to apply the Roman-Dutch law, De Wet 1985: 294 has criticised this judgement for unacceptably imposing a forced and unjustified interpretation on the writers in order to bring South African law in line with the English Malicious Damage Act of 1861, and opined that the conduct concerned should simply be prosecuted as fraud. For a similar approach, see Snyman 2014: 542. This point was further affirmed in $R v$ Mabula 1927 AD 159 at 161; and in $R v$ Mataung 1953 (4) SA 35 (O) at 36.

$195 S v$ Van Zyl 1987 (1) SA 497 (O).

196 Idem at 502I-503A. The court also found that further indications in Van der Linden 247 in support of this interpretation are the example relating to sentence, namely that where a whole town or community was placed in danger, this would render the crime more serious, and the focus on the intention of the arsonist to commit the harm even where such intention was not achieved.

197 S v Van Zyl 1987 (1) SA 497 (O) at 503D-504J.

198 Idem at 505C. See Labuschagne 1987: 340. 
It has further been held in $S v$ Solomon, ${ }^{199}$ correctly, it is submitted, that the crime of conflagratio (the unlawful and intentional creation of a fire dangerous to the community) was unknown in our law. ${ }^{200}$ The court pointed out that the Roman law crime of incendium protected not only the interests of life and property, but also that of community safety. ${ }^{201}$ It follows that the crime of arson, which derives from the Roman-Dutch crime of brandstichting (and which in turn is derived from the crime of incendium) therefore includes in its ambit the protection of life, property and community safety.

\section{Rationale and structure of discussed crimes}

Having examined the current state of the South African law in respect of the crimes of arson and malicious injury to property, and the closely related developmental paths that have given rise to the current manifestations of these crimes, an analysis of the present position may be attempted. In terms of the rationale for each of the crimes, it is clear that the crime of malicious injury to property is correctly classified as a crime against property, ${ }^{202}$ and more particularly as a crime involving damage to property. ${ }^{203}$ Arson has traditionally been similarly categorised. However, these crimes require more detailed scrutiny. In this part of the contribution, the discussion of arson, which has seen more extensive development and application in South African law, precedes that of malicious injury to property, to facilitate comparison.

\section{Arson}

The recent authoritative judgement of the Supreme Court of Appeal in Dalindyebo, in approving the approach of the Appellate Division decision in Mavros, has confirmed that arson not only protects property, but also functions to protect the community against the danger associated with fires. This rationale may be masked by the rationale involving protection of property where the burning is of immovable property belonging to another; however, the rationale of protection of property plays no role where the object of the arson is the accused's own property. As was stated in Paizee -

[i]f a person has a dislike to his house, he has the right to burn it down if he chooses, but there is one other condition before he can claim to be perfectly guiltless of any crime, and that is in

$199 S$ v Solomon 1973 (4) SA 644 (C).

200 Followed in $S v$ Van Zyl 1987 (1) SA 497 (O) at 504. See, also, Richings 1974: 149. However, see De Wet 1985: 295.

$201 S$ v Solomon 1973 (4) SA 644 (C) at 649A-B.

202 See Burchell 2016: 685

203 See De Wet 1985: 286; Milton 1996: 763; Snyman 2014: 539. 
doing so he is doing no damage or harm to anyone else. The moment he does wilful damage to any other person by such act, then he commits the crime of arson..$^{204}$

The tension in these differing rationales underpinning a single crime of arson has been noted by Hunt: ${ }^{205}$

The crime of arson compounds elements of protection of property and of the community. If an ideal code were drafted, it might well be found desirable to split arson into two crimes, one crime concerned with protection of the community, and the other with protection of property.

This statement has met with judicial approval in $S v$ Solomon $^{206}$ and $S v$ Van Zyl. ${ }^{207}$ It is therefore evident that the crime of arson cannot simply be regarded as being a particular form of malicious injury to property, ${ }^{208}$ but rather that, whilst these crimes may well overlap, they are not the same, as they protect differing interests. As is evident from its developmental path, malicious injury to property has never been regarded as a crime protecting the interests of the community, as does arson in particular factual scenarios.

If one accepts the validity of the distinction between malicious injury to property and arson, then this inevitably impacts on the question whether it is valid to extend these crimes to include intending to claim from insurance the value of self-inflicted damage to insured property. Despite the principled objections of De Wet and Snyman, the extension of the crime of arson to incorporate the intention to commit insurance fraud is well established, and any doubts that the approach adopted in Mavros would be followed have been categorically dismissed in Dalindyebo (albeit without any discussion directed towards this particular issue). In his judgement in Mavros, Innes CJ notes that the Roman-Dutch writers were "neither as definite nor as unanimous as one would wish" insofar as the question whether the common-law crime of brandstichting, the antecedent of arson, covered the act of "wrongfully and maliciously setting fire to one's own house with intent to injure or defraud another". ${ }^{209}$ However, pacified by the fact that these texts were written before the advent of fire insurance, and emboldened by, in particular, the statements of the writers Carpzovius and Moorman to the effect that a person who sets fire to his own building "with no other purpose than that the conflagration may destroy the house of his neighbour" commits brandstichting, ${ }^{210}$ Innes CJ concluded as follows: ${ }^{211}$

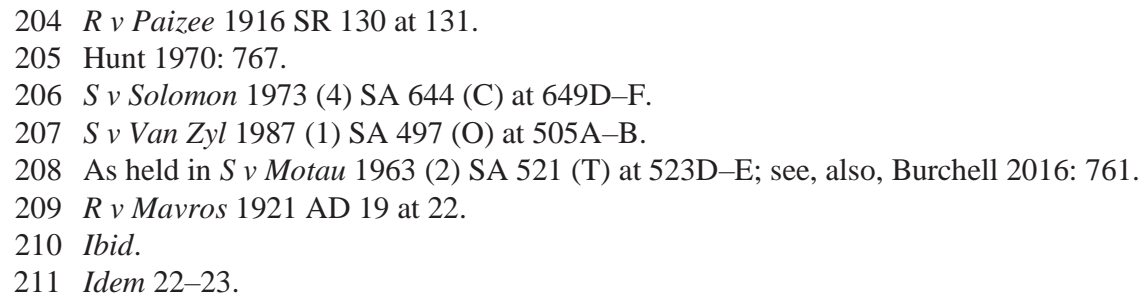


The authority of the last two writers [Carpzovius and Moorman] certainly supports the view that to set fire to one's own house with intent to burn the house of one's neighbour is brandstichting. And the intention to injure or destroy the building of another is what they point to as an incriminating element. Now the essence of crime is the intent with which the act is committed; and it is a very short step from the conclusion reached by Carpzovius and Moorman to the position that the owner of a house who sets fire to it wrongfully, maliciously and with intent to injure or defraud an insurer, commits the crime of brandstichting.

It is not entirely clear why the court favoured the views of these authors, as opposed to, for example, Van der Linden, whose work served as authority for the Hoffman decision, which was in turn relied upon by the court in Paizee (to which Innes CJ referred). It also seems plain that Carpzovius (along with Moorman, who relied extensively on Carpzovius's work in his own discussion of the $1 \mathrm{lw}^{212}$ ) was referring to the aspect of arson that protects the community against the danger of fire. The new rule extending the ambit of arson to include the protection of the insurer in its contractual relationship with the accused, in respect of the structure burnt by the accused, is thus founded on the aspect of the crime that seeks to protect the community from being harmed by the fire itself, rather than from any consideration underscoring the protection of private property. In short, the Mavros decision to recognise the criminalisation of setting fire to one's own property with the intent to harm the property of another is well established and uncontroversial. This approach simply recognises the danger that a fire poses to the habitation and well-being of those in its vicinity. However, to translate that principle into protection of an insurer in terms of the crime of arson, particularly where the crime of fraud in any event finds application, is considerably more shaky in terms of both logic and RomanDutch jurisprudence.

Whatever the principled problems, and, it is submitted, misapplication of the Roman-Dutch writings on the point, ${ }^{213}$ this issue is merely of academic importance insofar as the law of arson is concerned, where the ambit of the crime has been conclusively settled by Dalindyebo, and where there is strong precedent for the extension of the crime. In policy terms, this misshapen proscription is arguably the price we must pay for having a broadly framed crime that not only protects property interests, but also the interests of the community against the profound and pernicious damage that can be wrought by fire. In this regard, as argued above, ${ }^{214}$ arson has developed, like extortion, into a crime where the intention with which the accused acts will serve to convert an ostensibly lawful act into an unlawful one. In this way, the crime provides the broadest protection against possible threats to community safety; even if the fire that has been set to the accused's property does not spread to

212 Burchell \& Hunt 1970: 13 point out that Moorman's work relied heavily on Carpzovius and Matthaeus.

213 Similar criticism can be levelled at the cases of Hoffman and Paizee.

214 See text accompanying nn 65-68 supra. 
his neighbours, liability will follow because of the centrality of the intent element in respect of the crime. ${ }^{215}$

In the wake of the Dalindyebo judgement, it seems that we have the following legal position in respect of arson: where the setting on fire occurs in respect of the property of another, the standard definition of the crime pertains, namely the unlawful and intentional setting on fire of an immovable structure belonging to another. However, where the burning takes place in respect of the accused's own property, and the basis of criminalisation is the protection of the community from the danger created by the accused, the intention of the accused becomes very important. Since the burning of one's own property is not in itself unlawful, it is the intention with which the accused sets his own immovable structure on fire that transforms what would ordinarily be a lawful act into an unlawful act. In this regard, liability for this form of arson functions in the reverse manner to the justification ground of negotiorum gestio. In respect of negotiorum gestio, the accused's prima facie unlawful act is regarded as lawful on the basis of his intention to act in the interests of the other party. ${ }^{216}$ With regard to this form of arson, the ostensibly lawful conduct is rendered unlawful by the accused's intention to harm others through the burning (or at least, in the form of dolus eventualis, foreseeing the possibility of harm occurring to another, and reconciling himself to the risk of this occurring). The predominance of intention in determining unlawfulness in relation to the form of arson protecting community interests would also suggest a difference in the test for attempt. Arson in relation to the property of another would be assessed on the basis of the standard objective "commencement of the consummation" test, ${ }^{217}$ which assesses whether the accused has gone beyond the stage of preparation into the stage of consummation, in the context of the burning of another's immovable structure. ${ }^{218}$ However, the assessment of whether the form of arson that protects community interests has been attempted may involve a more subjective application of this test, with a stronger focus on what the accused intends, as opposed to his actual progress towards causing physical harm.

Insofar as the specific form of the crime of arson pertaining to insurance fraud is concerned (which, as we have seen, derives from the form of the crime protecting

215 See $R$ v Mavros 1921 AD 19 at 22, where the court states that "the essence of crime is the intent with which the act is committed".

216 Burchell 2016: 248 defines negotiorum gestio as occurring where "a person voluntarily performs an act in the interest of another with the intention of benefiting that other, but without the latter's knowledge or consent". There are objective constraints on this justification ground: the defence is only available where the consent of the other party could not be obtained before the accused acted; there must be reasonable grounds at the time of acting for believing that the other party would indeed consent; and the intrusion should not be excessive (Snyman 2014: 127-128).

217 See Burchell 2016: 551; Snyman 2014: 279; Hoctor 2015: 363.

218 See, for example, $R v$ Schoombie 1945 AD 541 for the application of this test leading to a conviction of attempted arson. 
community interests), it may be noted that this crime is in theory easy to commit, in that the elements of the crime are satisfied at the moment of setting on fire, provided the intent to commit insurance fraud is present. Nevertheless, the crime would seem to be difficult to prove. The probative difficulties relate to establishing the intention of the accused at the time of the commission of the act. Finding that the accused intended to set fire to the property of another typically does not present much difficulty, and in relation to the danger that setting one's own property alight holds for others, this too could generally be easily inferred. However, proof that the accused intended insurance fraud at the time of setting his own property alight presents more problems. The mere fact that the property is insured cannot suffice, and until the insurance claim is submitted, there would typically be little evidential foundation of the accused's criminal intent.

\section{Malicious injury to property}

While the extension of the ambit of the crime of arson has been accepted, whatever doctrinal qualms may be raised, it is submitted that the position in respect of malicious injury to property should be very different, for the following reasons.

First, as has been discussed, neither the case of Gervais, nor any of the decisions that have cited Gervais as authority, provide an authoritative basis for the extension of the ambit of malicious injury to property. Instead, the most formidable logic for extending the crime to include the intention to claim from an insurer the value of insured property that the accused (the insured party) damaged himself, is the doctrinal proximity of the crime of arson. This seems evident from the comments of Hunt that, whatever the illogicality of the extension of the ambit of malicious injury to property, "the matter seems to be settled for malicious injury to property by the arson cases", ${ }^{219}$ and Snyman's comment that in Mavros, the Appellate Division "held that conduct similar to that in Gervais does amount to arson (which is but a species of malicious injury to property)" and that since Mavros is an appeal court decision, "it is unlikely that the courts will depart from it". ${ }^{220}$ As stated above, a better view is that malicious injury to property and arson are distinct crimes, and therefore, despite their similarities, they are not bound to the same developmental path. If this point is accepted, given the weak authority in support of the Gervais line, the courts would not be bound by strong precedent, and would be at liberty to depart from this approach.

Secondly, there is no evidence in either the common-law sources of the crime, or in any of the jurisprudence before South African courts, that the crime of malicious injury to property was ever intended to protect community interests. Where destruction

219 Hunt 1970: 779.

220 Snyman 2014: 540. 
of property takes place during violent protests, for example, charges of malicious injury to property acknowledge the harm to proprietary interests, while the typical accompanying charges of public violence are directed at protecting the interests of the community. ${ }^{221}$ It can hardly be argued that to fraudulently claim the value of one's own insured property damaged by self-inflicted harm constitutes a crime against community interests, although it clearly amounts to fraud. The extension to the crime of arson, flowing from a broader protection of not only property, but also community protection, should therefore not apply to malicious injury to property. Fire-setting is clearly an activity that may have consequences for the wider community; not so damage to the property of another individual. To base the extension of the ambit of malicious injury to property on the wider conception of criminality in the context of arson, is simply incorrect.

Thirdly, it is important to consider a variety of constitutional aspects that come into play in the context of criminalisation. It is essential that the blunt power of the state, imposed through the operation of the criminal law, is duly restrained by considerations that operate to protect the individual. A central concern is that of fair labelling, which seeks to ensure that "widely felt distinctions between kinds of offences and degrees of wrongdoing are respected and signalled by the law", and that where people "reasonably regard two types of conduct as different, the law should try to reflect that difference". ${ }^{222}$ The operation of this principle helps to ensure proportionality in terms of the response to law-breaking, assisting the educative or declaratory function of the law and ensuring fairness, in that offenders are "labelled and punished in proportion to their wrongdoing". ${ }^{223}$ While the basis of both arson and malicious injury to property - damage to physical property and real rights in property - may be said to be in accordance with the principle of fair labelling, the extraneous punishment of fraud under arson and malicious injury to property seems a far cry from what people would reasonably expect to reside within the ambit of these crimes. Again, despite this concern, it is unlikely that the definition of arson will be altered in the teeth of authoritative endorsement in Mavros and Dalindyebo, but there is no reason on grounds of policy (as the crime of fraud covers this form of wrongdoing) or principle (as argued above) why the crime of malicious injury to property should sustain this ill-fitting extension.

21 Burchell 2016: 777 classifies public violence, "the unlawful and intentional commission by a number of people acting in concert of acts of sufficiently serious dimensions that are intended to forcibly disturb the public peace or security or to invade the rights of others", as a crime against community interests, while Milton 1996: 71 categorises public violence as a crime against public order.

22 Ashworth \& Horder 2013: 77. This concern was noted earlier with regard to the use of the word "malicious" in the nomenclature of the crime.

23 Ibid. 


\section{Concluding remarks}

It is therefore submitted that the definition of the crime of malicious injury to property should be "unlawfully and intentionally damaging the property of another, or one's own property in respect of which another person has a right of possession or special interest". ${ }^{224}$ Furthermore, it is submitted that since the extension to the crime based on the Gervais case and the uncritical identification with the crime of arson are mistaken, the definitions that seek to encompass such extension ought not to be followed. ${ }^{225}$

In respect of arson, for the reasons discussed, the definition of this crime has been confirmed in the Dalindyebo case, rendering further detailed analysis thereof redundant. The court cites Milton's definition with approval:226 "[a]rson consists in unlawfully setting an immovable structure on fire with intent to injure another." Nonetheless, it is submitted that the further qualifying statement of the Supreme Court of Appeal in Dalindyebo requires some modification. The court, somewhat curiously, states that the crime is committed where a person "wrongfully and/or maliciously" sets fire to his own immovable property with the requisite intention. This is problematic. "Wrongfully" should really be "unlawfully", 227 and "wrongfully" is not an alternative term for "maliciously", which in its own right creates terminological difficulties, not least in the context of the crime of malicious injury to property. ${ }^{228}$ The definition in Dalindyebo serves to correct the definition offered by Snyman, who, while including setting the property of another alight, and setting his own property alight in order to claim the value from the insurer, does not include setting one's own immovable property alight with the intention to harm another as a result of the burning (the basis of the decision on the facts in Dalindyebo). ${ }^{229}$ The definition of Kemp et al is also incomplete. It correctly covers the unlawful and intentional setting alight (by "X") of the property of another ("Y"), and further includes the unlawful and intentional setting alight of "the immovable

224 This definition amplifies the definition favoured by scholars, such as Milton, Burchell and De Wet, and by the leading case of $R v$ Mashanga - see $\mathrm{n} 23$ supra - to explicitly indicate that the crime also protects the possessor's right of possession (in the same way as does the crime of theft).

225 It is submitted that the second leg of Snyman's (2014: 539) definition (namely intentionally and unlawfully damaging one's "own insured property, intending to claim the value of the property from the insurer") ought to be dispensed with. The definition in Kemp et al 2018: 456 is more acceptable, but it is submitted that including "property belonging to himself in which [another person] has a substantial interest" also does not avail, as this begs the question as to what a "substantial interest" entails.

$226 S$ v Dalindyebo 2016 (1) SACR 329 (SCA) par 63.

227 Whereas "wrongfulness" refers to the causing of legally reprehensible or unreasonable prejudice in the context of the law of delict (see Neethling, Potgieter \& Visser 1999: 35), all crimes require "unlawfulness" (see Hoctor 2017: par 37).

228 See the text accompanying nn 20-22 supra.

229 Snyman 2014: 542 . 
property of $\mathrm{X}$ in which $\mathrm{Z}$ has an interest". ${ }^{230}$ However, what about the setting alight of X's own property with the intent of damaging the property of another?

And so, having followed developmental paths from somewhat indirect and unclear Roman and Roman-Dutch law origins, through the influence of English law in the form of the Malicious Damage Act of 1861 - nowhere directly acknowledged, but no doubt influential - the crimes of arson and malicious injury to property continue to play an important role in modern South African criminal law. Based on its twin rationales of protection of property and protection of the community, arson operates as a broadly defined crime of serious import. The focus on the accused's state of mind in the application of this crime underscores the policy concerns of the gravity and danger associated with intentional fire-setting, not only for the person directly associated with the structure, but also for the community generally. Malicious injury to property, on the other hand, for all its significance as a primary basis for protection of property, has no focus on the protection of the community. Primarily as a result of its perceived (and in part, actual) doctrinal proximity to arson, and not based on common-law sources or solid judicial precedent, malicious injury to property has been regarded as having been extended in its ambit, in the same way as has arson. However, as a clearly distinguishable crime, based on its own rationale, this is neither a necessary nor a welcome development. It is submitted that fraudulent wrongdoing should be punished as fraud, and that the only development of the crime that should be welcomed is the recognition of the protection of the rights of the possessor of property.

\section{Bibliography}

Allen, RE (ed) (1991) Concise Oxford Dictionary of Current English 8 ed (London)

Ashworth, A \& J Horder (2013) Principles of Criminal Law 7 ed (Oxford)

Burchell, EM \& PMA Hunt (1970) South African Criminal Law and Procedure Vol I: General Principles of Criminal Law (Cape Town)

Burchell, J (2016) Principles of Criminal Law 5 ed (Cape Town)

Carpzovius, B (1772) Practica nova imperialis Saxonica rerum criminalium in partes tres divisa (tr into Dutch by D van Hogendorp Verhandeling der Lijfstraffelijke misdaaden en haare berechtinge getrokken uyt de schriften van den heer Benedictus Carpzovius 2 vols) 2 ed (Amsterdam)

De Wet, JC (1985) De Wet \& Swanepoel Strafreg 4 ed (Durban)

De Wet, JC \& HL Swanepoel (1949) Strafreg (Durban)

Gardiner, FG \& CWH Lansdown (1919) South African Criminal Law and Procedure Vol II: Specific Offences (Cape Town)

230 Kemp et al 2018: 457. 


\section{SHANNON HOCTOR}

Hoctor, S (2013) "The nature of the crime of arson in South African law" Fundamina 19(2): $321-332$

Hoctor, S (2015) "The (surprising) roots of the test for criminal liability for interrupted attempt in South African law" SACJ 28(3): 363-372

Hoctor, SV (2017) “Criminal law” vol 11 in WA Joubert (ed) The Law of South Africa 3 ed (Durban)

Hunt, PMA (1970) South African Criminal Law and Procedure Vol II: Common-law Crimes (Cape Town)

Kemp, GP et al (2018) Criminal Law in South Africa 3 ed (Cape Town)

Labuschagne, JMT (1987) "Brandstigting van jou eie goed” De Jure 20(2): 340-344

Lansdown, CWH, WG Hoal \& AV Lansdown (1957) Gardiner and Lansdown South African Criminal Law and Procedure Vol II: Specific Offences 6 ed (Cape Town)

Matthaeus, A (1987) De Criminibus ad libros XLVII et XLVIII Digestorium commentarius (tr into English by M Hewett \& BC Stoop On Crimes: A Commentary on Books XLVII and XLVIII of the Digest vol 2) (Cape Town)

Milton, JRL (1996) South African Criminal Law and Procedure Vol II: Common-law Crimes 3 ed (Cape Town)

Moorman, J \& JJ van Hasselt (1764) Verhandelinge over de misdaden en der selver straffen (Arnhem) (throughout referred to as "Moorman")

Neethling, J, JM Potgieter \& PJ Visser (1999) Law of Delict 3 ed (Durban)

Reinecke, MFB, JP van Niekerk \& PM Nienaber (2013) “Insurance part 2" vol 12(2) in WA Joubert (ed) The Law of South Africa 2 ed (Durban)

Richings, FG (1974) “Conflagratio" SALJ 91: 149-152

Robinson, OF (1995) The Criminal Law of Ancient Rome (Baltimore)

Snyman, CR (2014) Criminal Law 6 ed (Durban)

Van der Keessel, DG (1969) Praelectiones ad jus criminale (tr into English \& ed by B Beinart \& P Van Warmelo Lectures on Criminal Law vol 3) (Cape Town)

Van der Linden (1904) Rechtsgeleerd, Practicaal en Koopmans Handboek (tr into English by Sir H Juta Institutes of Holland or Manual of Law, Practice, and Mercantile Law...) 5 ed (Cape Town)

Van Leeuwen, S (1820) Rooms-Hollands Regt (tr in to English by Sir A Johnston Commentaries on the Roman-Dutch Law) (London)

Voet, J (1955) Commentarius ad Pandectas (tr into English by P Gane The Selective Voet Being the Commentary on the Pandects by Johannes Voet vol 7) (London)

Zimmermann, R (1990) The Law of Obligations - Roman Foundations of the Civilian Tradition (Cape Town)

\section{Case law}

AJ Bruyns v Regina (1901) 22 NLR 75

Arnold v Terblanche 1961 (4) SA 229 (T) 


\section{CRIMINALISATION OF DAMAGE TO PROPERTY}

Director of Public Prosecutions, Transvaal v Minister of Justice and Constitutional Development 2009 (2) SACR 130 (CC)

Gourlie \& Verkouteren v The State (1896) 3 Off Rep 68

JJ Raw v Clerk of Peace, Pietermaritzburg County (1884) 5 NLR 292

Kohrs v Rex 1940 NPD 11

Njokweni $v$ Rex 1946 NPD 400

Queen v Charlie Shangaan (1883) 2 HCG 433

Queen v Enslin (1885) 2 Buch AC 69

Queen v Johannes (1880-1881) 1 EDC 93

Queen v Reikert (1874) 4 Buch 142

$R v$ Bhaya 1953 (3) SA $143(\mathrm{~N})$

$R$ v Blore 1934 OPD 62

$R v$ Bowden 1957 (3) SA 148 (T)

$R v$ Gervais 1913 EDL 167

$R v$ Hoffman; $R v$ Saachs \& Hoffman (1906) 2 Buch AC 342

$R v$ Innocent 1966 (2) SA 362 (R)

$R$ v Janoo 1959 (3) SA 107 (A)

$R v K 1956$ (2) SA 217 (T)

$R v$ Kewelram 1922 AD 213

$R v$ Mabula 1927 AD 159

$R v$ Malamu Nkatlapaan 1918 TPD 424

$R v$ Mandatela 1948 (4) SA 985 (E)

$R v$ Manuel 1959 (1) SA 677 (C)

$R v$ Maritz 1956 (3) SA 147 (GW)

$R v$ Maruba 1942 OPD 51

$R v$ Mashanga 1924 AD 11

$R v$ Mataung 1953 (4) SA $35(\mathrm{O})$

$R$ v Mavros 1921 AD 19

$R v$ Mohale 1955 (3) SA 563 (O)

$R v$ Mtshilselwe 1957 (3) SA 313 (E)

$R v N 1955$ (2) SA 647 (T)

$R v$ Ncetendaba 1952 (2) SA 647 (SR)

$R v$ Ndaba 1942 OPD 149

$R v$ Paizee 1916 SR 130

$R v$ Pope 1953 (3) SA 890 (C)

$R v$ Rudolph 1935 TPD 79

$R v$ Schoombie 1945 AD 541

$R v$ Shelembe $1955(4) \mathrm{SA} 410(\mathrm{~N})$ 


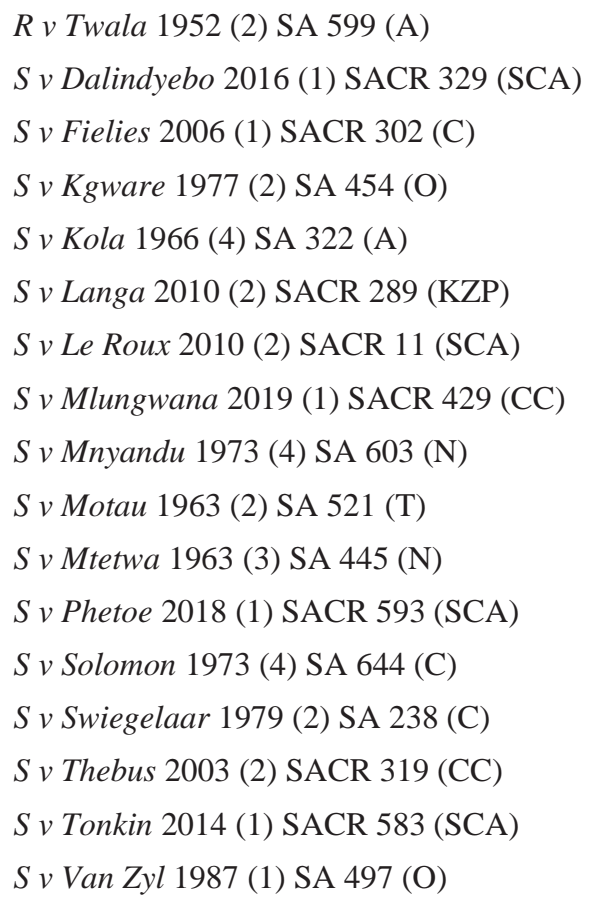

\section{Constitution}

Constitution of the Republic of South Africa, 1996

\section{Legislation}

\section{South Africa}

Child Justice Act 75 of 2008

Criminal Procedure Act 51 of 1977

Explosives Act 15 of 2003

Firearms Control Act 60 of 2000

Game Theft Act 105 of 1991

Immigration Act 13 of 2002

Prevention of Organised Crime Act 121 of 1998

Private Security Industry Regulation Act 56 of 2001 
CRIMINALISATION OF DAMAGE TO PROPERTY

\section{United Kingdom}

Malicious Damage Act, 1861 (24 \& 25 Vict c 97) 